\title{
Changes in Study Habits of Chinese Adolescents and Factors Supporting These Habits-Focusing on the Transition Period from Elementary School to Junior High School
}

\author{
Kohei Okado',2, Noriyuki Kida $^{2}$, Takeshi Sakai \\ ${ }^{1}$ Vories Gakuen Omi Brotherhood Junior High School, Shiga, Japan \\ ${ }^{2}$ Kyoto Institute of Technology, Kyoto, Japan \\ ${ }^{3}$ Kyoto Women's University, Kyoto, Japan \\ Email: cowhey@gmail.com
}

How to cite this paper: Okado, K., Kida, N., \& Sakai, T. (2018). Changes in Study Habits of Chinese Adolescents and Factors Supporting These Habits-Focusing on the Transition Period from Elementary School to Junior High School. Psychology, 9, 10811094.

https://doi.org/10.4236/psych.2018.95068

Received: April 27, 2018

Accepted: May 22, 2018

Published: May 25, 2018

Copyright $\odot 2018$ by authors and Scientific Research Publishing Inc. This work is licensed under the Creative Commons Attribution International License (CC BY 4.0).

http://creativecommons.org/licenses/by/4.0/

(c) (i) Open Access

\begin{abstract}
Changes in study habits of Chinese adolescents and factors supporting these habits were investigated through a survey on study habits and through interview surveys focusing on the transition period from elementary school to junior high school. Participants were students attending public schools in China (Shanghai, Beijing, Nanjing, and Zhenjiang). A questionnaire was conducted in the elementary school for $6^{\text {th }}$ grade students and in the junior high schools for $1^{\text {st }}$ through $3^{\text {rd }}$ grade students. Moreover, in Beijing, results of exams (Chinese language, Math, English) were collected. The results indicated a high correlation between study habits and academic results. And, a decline in study habits of students from elementary to junior high school was not observed in this study. Furthermore, the results of the interview surveys indicated that high results of Chinese education were not achieved only through cramming, and that "learning ahead" is significant. In addition to the adequate support provided by teachers and parents, a correlation between school lessons and high academic results was also observed.
\end{abstract}

\section{Keywords}

Chinese Education, Adolescence, Transition from Elementary School to Junior High School, Shanghai, Beijing, Study Habits, Parents, Advanced School Lessons

\section{Introduction and Aims}

Adolescence (10 - 18 years of age) is a period of many changes. Gutman and 
Midgley (2000) indicated that this period is "a time of self-discovery, expanding horizons, expanding independence," and physical and emotional development. Moreover, how adolescents spend this period affect their lifetime outcomes (Gutman \& Midgley, 2000). Especially, the early adolescence, from 12 - 15 years of age is an important period. Carnegie Council on Adolescent Development (1995) stated that 10-14 years of age is the turning point in life. Positive educational experience during this period leads to acquiring healthy habits, whereas poor academic results decline such habits. One environmental change in this period is the transition from elementary to junior high school. Carnegie Council on Adolescent Development (1995) indicated the significance of this environmental change in this period.

Anderman and Midgley (1997) analyzed differences in learning between elementary school and junior high school students. According to them, elementary school students tend to try to improve their abilities and seek the achievement of task performance. On the other hand, junior high school students tend to seek relative evaluation and try to obtain results, such as finding the correct answers. Changes in this transition period are known to affect academic results significantly. Many young people experience a decline in academic results in this period (Eccles \& Midgley, 1989; Eccles et al., 1993). Simmons and Blyth (1987) reported that changes in this period sometimes lead not only to a decline in academic results, but also to failures, or withdrawal from school.

It is important to develop support systems for preventing such failures and withdrawal. Gutman and Midgley (2000) regarded roles of classmates, teachers, and parents as factors in supporting junior high school students. Moreover, Eccles and Harold (1993) indicated that family involvement in adolescence has positive effects on academic results. Furthermore, Gutman and Midgley (2000) stated that when parents often talk about school life and have interest in learning activities, children recognize the school as important and become encouraged to do their best at school. Wentzel (1998) indicated parents' support increases junior high school students' interest in school and improve their motivation for achieving social goals. Rumberger (1995) analyzed the tendencies of junior high school students that dropped out of school and indicated parents' support contributes to stable school life. Moreover, study support provided at home affects academic results, through cooperation with the school. According to Carnegie Council on Adolescent Development (1995), however, such support provided by parents decreases during elementary school days and nearly disappears in junior high school, although it would be effective for all the students, regardless of their school year.

Strong correlations have been reported between junior high school students' interest in studying and academic results (Wentzel, Weinberger, Ford, \& Feldman, 1990). Singh et al. (2002) indicated that academic time, attitude, motivation had a strong effect on academic results in mathematics and science. Moreover, Dörnyei, Z., \& Ushioda, E. (2011) indicated when students recognized the contents of school lessons were worth listening to, their motivation for learning 
increased. As described above, various factors affect the academic results of junior high school students. It is necessary to quantitatively assess junior high school students' motivations and interests in studying, examine changes, and conduct analysis, as well as develop interventions. Moreover, it is essential to develop systems for providing study support for junior high school students and the support provided by parents and teachers is considered especially important.

Recently, China has been achieving internationally remarkable results in junior high school education. In the Program for International Students Assessment (PISA) 2009 implemented by OECD, Shanghai was at the top in mathematical literacy, reading, and scientific literacy. Shanghai also was at the top in all PISA 2012 items. It is obvious that Chinese junior high school education has achieved much progress (PISA, 2009, 2012). In China, educational reforms have been advancing since 1993. The Government of the People's Republic of China promulgated "Guidelines on the reform and development of education" in 1993, and "quality-oriented education" was advocated (Council of Local Authorities for International Relations, CLAIR, 2008). The $3^{\text {rd }}$ article of the Compulsory Education Law of the People's Republic of China states; "In compulsory education, the state policy on education shall be implemented and quality-oriented education shall be conducted to improve the quality of education and enable children and adolescents to achieve all-round development-morally, intellectually as well as physically-so as to lay the foundation for cultivating well-educated and self-disciplined builders of socialism with high ideals and moral integrity" (CLAIR, 2008).

Quality-oriented education is an education for developing the students' creative spirit and practical abilities while being critical of conventional education such as "education only for the elite," "overemphasis on knowledge," and "cramming" (CLAIR, 2008). It aims to develop "quality that is formed in the process of human development including two major factors, i.e., natural and social factors." It is composed of "political ideas, moral and scientific quality, as well as physical and psychological quality." Quality-oriented education is designed to "achieve the well-balanced development of these items" (Wang, 2004). Achievement of Chinese education is the result of the educational reforms described above. Therefore, it is considered effective to analyze Chinese junior high school education for obtaining useful suggestions for the development of education. However, few studies have been conducted on junior high school education in China and Chinese junior high school students' awareness of learning. Especially, their study habits are not known. Okado et al. (2017a) examined Japanese private junior high school students' learning habits, by developing a questionnaire for quantitatively assessing their home study habits and subject study habits. The results indicated that these study habits significantly declined during the six months of the transition period from elementary school to junior high school. Moreover, the decline continued until the fall in the $3^{\text {rd }}$ grade of junior high school, and subject learning habits had a strong correlation 
with academic results.

This study aims to obtain useful suggestions for improving education in Japan and other countries, by investigating Chinese children's study habits and academic results. The following three tasks were planned; 1) to analyze Chinese junior high school students' motivation for learning and interest in study using a questionnaire, 2) to examine support provided by Chinese parents, especially for studying in school, through an interview survey, and 3) to observe school lessons in China and conduct an interview survey, to obtain findings for increasing students' learning motivation and learning time by improving the quality of school lessons.

\section{Methods}

\subsection{Survey on Study Habits}

\subsubsection{Participants}

Survey was conducted at a junior high school in Shanghai (including $6^{\text {th }}$ graders), Beijing, Nanjing, and Zhenjiang. All schools were "key schools" in China. Regarding Shanghai and Beijing, they were selected as subjects for the survey because of the target area of PISA conducted by the OECD. Regarding Nanjing and Zhenjiang, they were selected as subjects for the survey because they were with an emphasis on international education and foreign language education. The Nanjing and Zhenjiang schools have a special curriculum on English language education, and some programs are for learning languages other than English.

Students $(\mathrm{N}=315)$ attending public schools in China (Shanghai, Beijing, Nanjing, and Zhenjiang) participated in the survey. They included $6^{\text {th }}$-grade elementary school students $(\mathrm{N}=32), 1^{\text {st }}$-grade junior high school students $(\mathrm{N}=$ $148), 2^{\text {nd }}$-grade junior high school students $(\mathrm{N}=90)$, and $3^{\text {rd }}$-grade junior high school students $(\mathrm{N}=45)$. In Shanghai, Beijing, and Nanjing, students in only one grade participated, i.e., in Shanghai, $6^{\text {th }}$-grade elementary school students $(\mathrm{N}$ $=32$ ), in Beijing, $1^{\text {st }}$-grade junior high school students $(\mathrm{N}=103)$, and in Nanjing, $2^{\text {nd }}$-grade junior high school students $(\mathrm{N}=46)$. On the other hand, in Zhenjiang, students in three grades attending a junior high school participated (45 $1^{\text {st }}$ graders, $442^{\text {nd }}$ graders, and $453^{\text {rd }}$ graders).

In the survey, receiving the cooperation of teachers from Chinese schools affiliated with a Japanese school and a researcher from China who teaches at a Japanese university. School observations, questionnaire surveys and interview surveys were conducted with the consent of teachers of the surveyed schools. The common features of these participants are that there are entrance examinations for entering the school, the learning environments are well established, and the quality of teachers is high. Because these schools carry out entrance examinations, the student's academic results are above average. In addition, these junior high schools are education priority schools; enriched environments are prepared in educational contents and educational facilities. Furthermore, employment standards and training systems have been established for teachers, and the qual- 
ity of teachers is also higher than the average.

\subsubsection{Contents of the Survey}

The thirteen question items developed by Okado et al. (2017a) were used in this study. These items included; conditions of doing homework, review and preparation for classes, preparations for minor tests, development of a study plan for regular exams, development of a daily study plan, attitudes in the class, how to take notes, the frequency of speaking in class, use of a syllabus, learning time during after-school activities, learning time on weekdays, and learning time on holidays. Participants responded using a four-point scale in regards to conditions of doing homework, review and preparation for classes, preparations for minor tests, development of a study plan for regular exams, development of a daily study plan, attitudes in the class, how to take notes, learning time during after-school activities, learning time on weekdays, and learning time on holidays, partly a two-point scale in regards to use of a syllabus and a three-point scale in regards to the frequency of speaking in class. Moreover, scores of mock exams (English, math, and Chinese language) were inquired in one class $(\mathrm{N}=54)$ at a junior high school in Beijing.

\subsubsection{Survey Period and Implementation Methods}

The Survey was conducted in October 2016 at schools in Beijing, December 2016 in Zhenjiang, and December 2017 in Shanghai as well as in Nanjing. The Chinese academic year starts from September. Therefore, the surveys were conducted at the beginning of a new academic year and were conducted during classes. Computers were used in the school in Zhenjiang. A questionnaire was administered in schools other than in Zhenjiang. Teachers distributed the questionnaire and collected them after the students responded.

\subsubsection{Procedures of Analysis}

Responses to the questionnaire were compared among the grades. Regarding the school in Zhenjiang, the comparison was made among the grades, separately from other schools. In the junior high schools in Beijing, the Learning Habit Scale developed by Okado et al. (2017a) was used. The study habit scores were calculated based on home study habit scores and subject study habit scores, and their correlations with academic results were examined. Analyses were conducted using SPSS23.0.

\subsection{Interview Survey}

\subsubsection{Schools that Participated in the Survey}

The interview survey was conducted at a junior high school in Shanghai (including $6^{\text {th }}$ graders), in Zhenjiang, and in Nanjing. All three schools were "key schools," and students' academic results were above average.

\subsubsection{Survey Period and Contents of the Survey}

The survey was conducted in December 2017 at schools in Shanghai and Nanj- 
ing, and in December 2016 in Zhenjiang. School visits and observations of classes were conducted. After that, interviews were conducted with teachers. In Shanghai, after observing a mathematics class of 6th graders in elementary school, the interview survey was conducted to teachers about school education in Shanghai. In addition, the interview survey was conducted by email too. In Nanjing, after observing an English class of 1st graders in junior high school, the interview survey was conducted to teachers about school education in Nanjing. In addition, the interview survey was conducted by email too. Moreover, an observing was conducted in the classroom meeting for the next day. In Zhenjiang, interview survey was conducted to school president about school education. In addition, the interview survey was conducted by email too.

\section{Results}

\subsection{A Questionnaire about Study Habits}

\subsubsection{Differences Depending on the School Year}

Table 1 shows the survey results of study habits. A one-way ANOVA was conducted by regarding the grade $\left(6^{\text {th }}\right.$-grade in elementary school, $1^{\text {st }}$-grade, and $2^{\text {nd }}$-grade in junior high school) as a between-subjects factor. A significant main effect was indicated for all the items excluding minor tests, taking notes, and learning time on holidays. The results of multiple comparisons indicated that the score of homework was highest in the $6^{\text {th }}$ graders, and that of $2^{\text {nd }}$ graders was significantly higher than $1^{\text {st }}$ graders. Moreover, scores for reviews, attitudes in class, time spent on after-school activities, learning time on weekdays, and subject study habits in $6^{\text {th }}$ graders and $2^{\text {nd }}$ graders were significantly higher scores than $1^{\text {st }}$ graders. Furthermore, scores for preparations, daily plans, speech in class, syllabuses, and study time at home in $6^{\text {th }}$ graders were significantly higher than $1^{\text {st }}$ and $2^{\text {nd }}$ graders. Also, scores of plans for tests in $2^{\text {nd }}$ graders were significantly higher than $6^{\text {th }}$ and $1^{\text {st }}$ graders.

Table 2 shows the survey results at a school in Zhenjiang, where computers were used. A one-way ANOVA was conducted with the grade as a between-subjects factor. A significant main effect was indicated for the items including preparations, daily plans, speech in class, and study time on holidays. The results of multiple comparisons indicated that the score of preparations in the $1^{\text {st }}$ graders was significantly higher than $2^{\text {nd }}$ graders. Moreover, the score of daily plans in $2^{\text {nd }}$ graders was significantly higher than $3^{\text {rd }}$ graders. Furthermore, the score of speech in class in $1^{\text {st }}$ graders was significantly higher than $3^{\text {rd }}$ graders. Also, the score of study time on holidays in $2^{\text {nd }}$ graders was significantly higher than $1^{\text {st }}$ graders.

\subsubsection{Correlation Coefficients between Study Habits and Academic Results}

Table 3 shows correlation coefficients between study habits and academic results in $1^{\text {st }}$-grade junior high school students in Beijing. Significant positive correlations were shown between the results of all the subjects and homework, reviews, 
Table 1. The survey results of study habits.

\begin{tabular}{|c|c|c|c|c|}
\hline & $6^{\text {th }} \operatorname{grade}(\mathrm{A})$ & $1^{\text {st }}$ grade $(\mathrm{B})$ & $2^{\text {nd }}$ grade $(C)$ & $\begin{array}{c}\text { Multiple } \\
\text { comparison }\end{array}$ \\
\hline & $M \pm S D$ & $M \pm S D$ & $M \pm S D$ & \\
\hline Homework & $3.94 \pm 0.24$ & $3.77 \pm 0.67$ & $3.56 \pm 0.85$ & $\mathrm{~B}<\mathrm{C}<\mathrm{A}$ \\
\hline Reviews & $3.32 \pm 0.64$ & $2.82 \pm 1.01$ & $3.45 \pm 0.78$ & $\mathrm{~B}<\mathrm{A}, \mathrm{C}$ \\
\hline Preparations & $3.53 \pm 0.62$ & $2.88 \pm 1.06$ & $3.04 \pm 1.02$ & $\mathrm{~B}, \mathrm{C}<\mathrm{A}$ \\
\hline Small tests & $3.47 \pm 0.66$ & $3.32 \pm 0.98$ & $3.43 \pm 0.85$ & \\
\hline Test plans & $3.24 \pm 0.61$ & $2.75 \pm 1.12$ & $3.55 \pm 0.90$ & $\mathrm{~B}<\mathrm{A}<\mathrm{C}$ \\
\hline Daily plans & $3.53 \pm 0.56$ & $3.17 \pm 1.11$ & $3.26 \pm 0.87$ & $\mathrm{~B}, \mathrm{C}<\mathrm{A}$ \\
\hline Attitudes in class & $3.41 \pm 0.61$ & $3.04 \pm 0.87$ & $3.36 \pm 0.74$ & $\mathrm{~B}<\mathrm{C}, \mathrm{A}$ \\
\hline Taking notes & $3.59 \pm 0.56$ & $3.44 \pm 0.99$ & $3.51 \pm 0.86$ & \\
\hline Speech in class & $3.62 \pm 0.49$ & $3.17 \pm 0.85$ & $3.36 \pm 0.87$ & $\mathrm{~B}, \mathrm{C}<\mathrm{A}$ \\
\hline Syllabus & $3.74 \pm 0.51$ & $3.36 \pm 1.25$ & $3.23 \pm 0.98$ & $\mathrm{C}, \mathrm{B}<\mathrm{A}$ \\
\hline $\begin{array}{c}\text { Time of after-school } \\
\text { activities }\end{array}$ & $2.62 \pm 1.37$ & $2.08 \pm 1.36$ & $2.79 \pm 1.47$ & $\mathrm{~B}<\mathrm{A}, \mathrm{C}$ \\
\hline Study time on weekdays & $2.59 \pm 0.99$ & $2.08 \pm 1.12$ & $2.53 \pm 1.30$ & $\mathrm{~B}<\mathrm{C}, \mathrm{A}$ \\
\hline Study time on holidays & $2.50 \pm 1.02$ & $2.66 \pm 1.22$ & $2.70 \pm 1.41$ & \\
\hline Home study habits & $3.53 \pm 0.36$ & $3.06 \pm 0.87$ & $3.24 \pm 0.73$ & $\mathrm{~B}, \mathrm{C}<\mathrm{A}$ \\
\hline Subject study habits & $3.65 \pm 0.37$ & $3.35 \pm 0.79$ & $3.55 \pm 0.67$ & $\mathrm{~B}<\mathrm{C}, \mathrm{A}$ \\
\hline
\end{tabular}

Table 2. The survey results of study habits at a school in Zhenjiang.

\begin{tabular}{|c|c|c|c|c|}
\hline & $1^{\text {st }} \operatorname{grade}(\mathrm{A})$ & $2^{\text {nd }} \operatorname{grade}(B)$ & $3^{\text {rd }} \operatorname{grade}(C)$ & Multiple \\
\hline & $M \pm S D$ & $M \pm S D$ & $M \pm S D$ & comparison \\
\hline Homework & $3.91 \pm 0.29$ & $3.80 \pm 0.55$ & $3.89 \pm 0.38$ & \\
\hline Reviews & $3.36 \pm 0.48$ & $3.26 \pm 0.63$ & $3.20 \pm 0.82$ & \\
\hline Preparations & $3.44 \pm 0.69$ & $3.15 \pm 0.77$ & $3.29 \pm 0.76$ & $\mathrm{~B}<\mathrm{A}$ \\
\hline Small tests & $3.58 \pm 0.62$ & $3.42 \pm 0.69$ & $3.38 \pm 0.78$ & \\
\hline Test plans & $3.14 \pm 0.55$ & $2.93 \pm 0.83$ & $3.18 \pm 0.89$ & \\
\hline Daily plans & $3.47 \pm 0.63$ & $3.79 \pm 0.47$ & $3.24 \pm 0.93$ & $\mathrm{C}<\mathrm{B}$ \\
\hline Attitudes in class & $3.49 \pm 0.63$ & $3.28 \pm 0.59$ & $3.51 \pm 0.55$ & \\
\hline Taking notes & $3.69 \pm 0.51$ & $3.84 \pm 0.37$ & $3.59 \pm 0.84$ & \\
\hline Speech in class & $3.73 \pm 0.45$ & $3.58 \pm 0.50$ & $3.41 \pm 0.58$ & $\mathrm{C}<\mathrm{A}$ \\
\hline Syllabus & $3.89 \pm 0.32$ & $3.88 \pm 0.32$ & $3.76 \pm 0.44$ & \\
\hline $\begin{array}{c}\text { Time of after-school } \\
\text { activities }\end{array}$ & $2.93 \pm 0.84$ & $2.54 \pm 0.82$ & $2.85 \pm 1.06$ & \\
\hline Study time on weekdays & $2.38 \pm 0.78$ & $2.66 \pm 0.88$ & $2.49 \pm 0.97$ & \\
\hline Study time on holidays & $2.62 \pm 0.83$ & $3.17 \pm 1.06$ & $3.07 \pm 0.92$ & $\mathrm{~A}<\mathrm{B}$ \\
\hline
\end{tabular}


Table 3. Correlations between study habits and academic results of 1st-grade junior secondary school students in Beijing.

\begin{tabular}{|c|c|c|c|c|c|c|c|c|}
\hline & $\begin{array}{l}\text { Chinese } \\
\text { language }\end{array}$ & & Math & & English & & Total & \\
\hline Homework & 0.402 & $* *$ & 0.387 & $* *$ & 0.358 & $* *$ & 0.418 & ** \\
\hline Reviews & 0.547 & $* *$ & 0.388 & $* *$ & 0.387 & $* *$ & 0.451 & ** \\
\hline Preparations & 0.274 & * & 0.173 & & 0.218 & & 0.229 & \\
\hline Small tests & 0.251 & & 0.209 & & 0.233 & & 0.268 & \\
\hline Test plans & 0.200 & & 0.081 & & 0.255 & & 0.204 & \\
\hline Daily plans & 0.271 & * & 0.211 & & 0.315 & * & 0.272 & * \\
\hline Attitudes in class & 0.351 & $* *$ & 0.344 & * & 0.386 & $* *$ & 0.389 & ** \\
\hline Taking notes & 0.332 & * & 0.310 & * & 0.278 & * & 0.311 & * \\
\hline Speech in class & 0.340 & * & 0.349 & * & 0.369 & $* *$ & 0.385 & ** \\
\hline Syllabus & 0.270 & * & 0.432 & $* *$ & 0.352 & $* *$ & 0.379 & ** \\
\hline $\begin{array}{c}\text { Time of after-school } \\
\text { activities }\end{array}$ & 0.224 & & 0.270 & & 0.301 & * & 0.278 & * \\
\hline $\begin{array}{l}\text { Study time on } \\
\text { weekdays }\end{array}$ & 0.222 & & 0.174 & & 0.217 & & 0.219 & \\
\hline $\begin{array}{l}\text { Study time on } \\
\text { holidays }\end{array}$ & 0.294 & * & 0.274 & * & 0.297 & * & 0.322 & * \\
\hline $\begin{array}{c}\text { Content of home } \\
\text { study }\end{array}$ & 0.420 & $* *$ & 0.496 & $* *$ & 0.377 & $* *$ & 0.459 & ** \\
\hline Home study habits & 0.395 & $* *$ & 0.355 & $* *$ & 0.375 & $* *$ & 0.390 & ** \\
\hline Subject study habits & 0.401 & $* *$ & 0.384 & $* *$ & 0.376 & $* *$ & 0.412 & $* *$ \\
\hline
\end{tabular}

${ }^{*} p<0.05 ;{ }^{* *} p<0.01$.

attitudes in class, taking notes, speech in class, syllabuses, study time on holidays, home study habits, and subject study habits. Preparation for the class had a significant positive correlation with the results of Chinese language tests. Daily plans had significant positive correlations with the results of Chinese language, English, and the total score. Moreover, time of after-school activities had significant positive correlations with English as well as the total score. On the other hand, there were no significant correlations between any of the subjects and minor tests, plans for tests, not the study time on weekdays.

\subsection{Interview Survey}

\subsubsection{Parents' Support}

Table 4 shows the results of the interview survey. An interview survey was conducted in three schools. The results indicated that systems for helping parents understand their children's learning conditions and providing support had been developed in all the schools. Parents were accurately informed about their children's learning condition, homework, and tasks using notebooks and emails. 
Table 4. Interview survey results.

\begin{tabular}{|c|c|c|c|c|c|c|}
\hline & $\begin{array}{c}\text { Using } \\
\text { notebook }\end{array}$ & $\begin{array}{l}\text { Using } \\
\text { email }\end{array}$ & $\begin{array}{c}\text { Contents of notebook } \\
\text { or email }\end{array}$ & $\begin{array}{l}\text { Parents' } \\
\text { checked }\end{array}$ & $\begin{array}{l}\text { Teacher's } \\
\text { checked }\end{array}$ & $\begin{array}{l}\text { Seminars for } \\
\text { parents }\end{array}$ \\
\hline Shanghai & None & Everyday & $\begin{array}{c}\text { Study contents and } \\
\text { homework }\end{array}$ & None & None & Frequently \\
\hline Nanjing & Everyday & None & Everyday homework & Everyday & Everyday & None \\
\hline Zhenjiang & Everyday & None & $\begin{array}{l}\text { Weekly schedule and } \\
\text { tasks, daily schedules, } \\
\text { assignment, and tasks }\end{array}$ & None & None & None \\
\hline
\end{tabular}

Concretely, at the junior high school in Zhenjiang, parent-teacher notebooks were used and weekly schedules and tasks, as well as daily schedules, homework, and tasks, were clearly written. At the school in Nanjing, everyday homework was written in the notebook, which the parents checked and signed. At the school in Shanghai, parents did not have to sign their names, but they were informed of study contents and homework by emails. Moreover, at this school, seminars for parents were frequently held to explain the importance of parents' support in junior high school education.

\subsubsection{Content of Classes}

The authors observed a $1^{\text {st }}$-grade math class at a elementary school and a $2^{\text {nd }}$-grade English class at a junior high school in Nanjing, and a $6^{\text {th }}$-grade math class at a elementary school in Shanghai. In the $1^{\text {st }}$-grade math class at the elementary school in which addition with carry-up was taught and the $6^{\text {th }}$-grade math class in which addition and subtraction including negative numbers were taught, teachers encouraged students to express the process of solving the problems and the ways of thinking, not only requiring them to answer the questions. Moreover, students were requested to find not only a single solution but also multiple solutions.

In the $2^{\text {nd }}$-grade English classes, the whole lesson was given in English, including questions and answers. The topic of the lesson was environmental problems. After discussing general environmental problems, the topic on Beijing 2022 Winter Olympics was talked about, and Chinese environmental problems were discussed. Finally, environmental problems in students' own life were debated, such as commuting by car, and discussions were based on concrete problems.

Based on the above, the following three factors are listed as characteristics of Chinese school lessons.

1) The logic of students thinking is inquired, and students are requested to answer logically.

2) Not only knowledge but also ideas and discussions based on critical thinking are required in classes.

3) Current topics and familiar issues are used as subjects of lessons. 


\section{Discussion}

\subsection{Study Habits}

The first aim of this study was to investigate changes in Chinese students' study habits in the transitional period from elementary school to junior high school using a questionnaire. The results indicated scores of some items were highest among the 6th-grade elementary students, whereas scores of about half of the items did not decline in the 1st and 2nd-grade junior high school students. Also, a decline was not observed among three grades of the same school excluding preparations. Okado et al. (2017a, 2017b) reported that Japanese students in a private junior high school had good study habits when entering the school, whereas a sharp decline was shown within a year. Compared to the case reported by Okado et al. (2017a, 2017b), Chinese students in the same age range investigated in the present study showed better study habits. A decline in study habits of Chinese students from elementary school to junior high school was not observed in this study.

Schools that participated in this study were relatively good public schools. The students had an entrance examination for enrolling in the schools, and their awareness of study and parents' consciousness of study support were rather high, which might have led to remarkably good study habits. Nevertheless, it should be noted that their study habits did not decline in the transition period. Therefore, factors related to study environment including schools and parents should be examined in detail.

\subsection{Parents' Support}

Both subject study habits and home study habits had strong correlations with academic results. The Japanese case study conducted by Okado et al. (2017b) indicated a correlation between subject study habits and academic results. However, a correlation between home study habits and academic results was not observed in their study. Okado et al. considered that it was difficult to reflect qualitative learning of home study, quantified by using the study habit scale, on academic results in Japanese junior high school education. A correlation between home study habits and academic results indicated in the present study is considered one of the characteristics of Chinese junior high school education. Therefore, roles of parents in home study were examined based on the results of the interview survey.

The results of the interview survey indicated that parents provided much study support in every school. Participants considered that steady home learning was very important in junior high school education, and they were responsible for it. Moreover, it was generally considered that schools should provide sufficient information to parents so that they could support their children in doing home study. Based on the above, the following three issues were indicated as factors increasing Chinese junior high school students' study habits: 1) schools give accurate information to parents, 2) parents understand the content of their 
children's learning and provide support, and 3) people generally consider that parents' support is indispensable for junior high school education.

The results of PISA indicated Chinese junior high school students' academic results and academic awareness were considerably high (PISA, 2009, 2012), which might represent effective functions of parents' support in junior high school education. The results of the interview survey indicated that not only some, but most Chinese parents were providing study support for their children.

Development of Information Technology (ICT) is making communication between teachers and parents smoother. At the school in Shanghai, teachers sent daily information to parents using ICT. In Japan, parent-teacher notebooks have been used since the 1970s (Miyatake, Takahara, \& Adachi, 1989). However, the notebooks are often used in education for handicapped children as a tool for supporting their school life, rather than as a communication tool between teachers and parents for supporting home study. Miyatake et al. (1989) listed the significance of parent-teacher notebooks as follows: 1) building trust between teachers and parents, 2) developing cooperation and consistency in guidance, 3) improving teaching skills, 4) recording the content of guidance, 5) recording children's development, 6) providing information for assessment, and 7) notifying children's achievements. It might be necessary to utilize parent-teacher notebooks for giving accurate information to parents, together with utilizing ICT.

\subsection{School Lessons}

In China, "Guidelines on the reform and development of education" was promulgated in 1993, and "quality-oriented education" was advocated. Quality-oriented education is education to develop students' creative spirit and practical ability, different from conventional education such as "education only for the elite," "overemphasis on knowledge," and "cramming" (CLAIR, 2008). It has been pointed out that severe examination systems and active participation in after-school activities including going to cram school are the characteristics of Chinese education (CLAIR, 2015). The results of the interview survey, however, suggested the high quality and maturity of school lessons. Logical thinking was developed through discussion, instead of the one-way flow of information. It is considered that such school lessons have increased students' interest, increasing their learning motivation and improving study habits.

Teacher employment and training systems in China might affect the high quality of school lessons. Elementary school teachers in China are required to graduate from the normal school for junior high school education ( 3 - 4 years) or to have a higher educational background. Junior high school teachers in China are required to graduate from specialized normal schools (corresponding to Japanese junior college, 2 - 3 years) or to have a higher educational background (Okada, 2011). The interview survey conducted in Shanghai indicated that when people want to become public junior high school teachers in Shanghai, a mas- 
ter's degree is required of those coming from Shanghai, and a doctoral degree is required of those coming from places other than Shanghai.

Regarding teacher training in China, based on "Guidelines for improving elementary and junior high school teacher training" (2011), teacher training systems with a 5 -year cycle based on a credit system has been developed and verification has started in several areas (Nonaka \& Ko, 2018). People who want to become certified teachers need to pass the national teachers' qualification examination. For updating the license, they are obliged to obtain 36 credits (360 hours) every five years (Nonaka \& Ko, 2018). Such teacher employment and training systems might have improved school lessons in China. In other words, it might be possible to improve the quality of classes by improving teachers' academic results and developing systems for teacher training.

Also in Japan, educational reform has advanced, such as the introduction of active learning and mutual learning (Ministry of Education, Culture, Sports, Science and Technology, 2014). However, it seems that Chinese education has a clear lead over Japan regarding independent learning. It is considered necessary to conduct studies for improving school lessons, by referring educational approaches in China and other countries'.

\section{Conclusions and Suggestions for Future Junior High School Education}

Study habits and academic results of Chinese students in the transition period from elementary school to junior high school were examined using a questionnaire and an interview survey. The results demonstrated good study habits in Chinese junior high school students, as well as a strong correlation between study habits and academic results. For improving students' study habits, teachers are taking various approaches to students and their parents, such as improving the quality of classes for increasing students' interest and giving accurate information to parents. Parents provide much study support to their children, such as checking their home study. Such support provided by schools and parents are considered useful for maintaining Chinese junior high school students' study habits and improve their academic results.

Social conditions in China might play a role in the background to the considerable support provided by parents and teachers. CLAIR (2015) stated that Chinese entrance examination brings about severe competition, the concentration of educational investigation at home has been advancing owing to the one-child policy, and Chinese society is an academic-oriented society. Based on such a social background and support by parents and schools, students' study habits are supported, and high-quality school lessons are provided in contemporary China.

The finding that high achievement of Chinese education was not brought about only by cramming and "learning ahead" is significant. In addition to the adequate support provided by teachers and parents, advanced school lessons are 
also delivered, including group work, discussions, debates, logical thinking, logical speech, and logical criticism. It is considered that by continuously participating in such classes every day, students' learning motivation would increase, study habits would be maintained, and academic results would be improved.

In the future, educational circumstances in China, especially the state of school lessons should be examined in detail. In addition to it is important to compare educational circumstances among various countries including China and Japan, from the perspective of study habits. Furthermore, it is important to investigate and compare educational circumstances among various countries including China, from the perspective of study habits. With a greater sample size and variance, we can increase confidence of any trends that were observed in the research conducted in this paper.

\section{References}

Anderman, E. M., \& Midgley, C. (1997). Changes in Achievement Goal Orientations, Perceived Academic Competence, and Grades across the Transition to Middle-Level Schools. Contemporary Educational Psychology, 22, 269-298, Article No. EP960926.

Carnegie Council on Adolescent Development (1995). Great Transitions: Preparing Adolescents for the New Century. Carnegie, New York.

CLAIR, Council of Local Authorities for International Relations (2015). Chugoku no kyouikuseido to ryugaku jijou (Chinese Education Systems and Conditions of Study Abroad). CLAIR REPORT NUMBER 427 (August 14, 2015).

Council of Local Authorities for International Relations (2008). Chugoku no Gimukyouiku (Compulsory Education in China). CLAIR REPORT NUMBER 325 (May 9, 2008).

Dörnyei, Z., \& Ushioda, E. (2011). Teaching and Researching Motivation (2nd ed.). Harlow: Longman.

Eccles, J. S., \& Harold, R. D. (1993). Parent-School Involvement during the Early Adolescent Years. Teachers College Record, 94, 568-587.

Eccles, J. S., \& Midgley, C. (1989). Stage/Environment Fit: Developmentally Appropriate Classrooms for Early Adolescence. In R. E. Ames, \& Ames, C. (Eds.), Research on Motivation in Education (Vol. 3, pp. 139-186). New York: Academic Press.

Eccles, J. S., Midgley, C., Buchanan, C. M., Flanagan, C., Mac Iver, D., Reuman, D., \& Wigfield, A. (1993). Development during Adolescence: The impact of Stage/Environment Fit. The American Psychologist, 48, 90-101. https://doi.org/10.1037/0003-066X.48.2.90

Gutman, L. M., \& Midgley, C. (2000). The Role of Protective Factors in Supporting the Academic Achievement of Poor African American Students during the Middle School Transition. Journal of Youth and Adolescence, 29. https://doi.org/10.1023/A:1005108700243

Ministry of Education, Culture, Sports, Science and Technology (2014). Shotou-chutou kyouiku ni okeru kyouikukatei no kijuntou no arikata ni tsuite (Criteria for Educational Curriculums of Primary and Secondary Education (Proposal)). Ministry of Education, Culture, Sports, Science and Technology. Nov. 20, 2014 http://www.mext.go.jp/b_menu/shingi/chukyo/chukyo0/toushin/1353440.htm

Miyatake, K., Takahara, N., \& Adachi, Y. (1989). Shougaiji kyouiku de shiyou sareru renrakucho ni kansuru chousakenkyu (Investigation on Parent-Teacher Notebooks used 
in Education for Handicapped Children). Tokushu kyouikugaku kenkyu (The Japanese Journal of Special Education), Lt7, 67-73.

Nonaka, Y., \& Ko, K. (2018). Chugoku Shanhai-shi no kyouinn kenshu seido ni kansuru chousahoukoku (Report on Teacher Training Systems in Shanghai, China). Kyouiku dezain kenkyu (The Japanese Journal of Educational Design), 9.

Okada, D. (2011). Chugoku no kinnen no kyouikukaikaku no doukou to kyoushi no shishitsu koujou no kadai (Recent Trends of Educational Reform in China and Improvement in Quality of Teachers). Hiroshima Kokusai Gakuin University Research Report, 44, 57-66.

Okado, K., Hamada, H., \& Kida, N. (2017a). Development of Learning Habit Scale and Situational Analysis of Japanese Junior High School Student Learning Habits. In International Conference on Applied Human Factors and Ergonomics (pp. 161-171). Cham: Springer.

Okado, K., Hamada, H., \& Kida, N. (2017b). Correlations between Changes in Study Habits and Academic Results in Junior High School Students-A Longitudinal Survey at a Private Junior High School. Psychology, 8, 2102-2113.

https://doi.org/10.4236/psych.2017.813133

PISA (2009). Programme for International Student Assessment (PISA 2009). Summary of PISA 2009. National Institute for Educational Policy Research.

http://www.mext.go.jp/component/a_menu/education/detail/_icsFiles/afieldfile/2010/ 12/07/1284443_01.pdf

PISA (2012). Programme for International Student Assessment (PISA 2012). Summary of PISA2012. National Institute for Educational Policy Research. http://www.nier.go.jp/kokusai/pisa/pdf/pisa2012_result_outline.pdf

Rumberger, R. W. (1995). Dropping Out of Middle School: A Multilevel Analysis of Students and Schools. American Educational Research Journal, 32, 583-625. https://doi.org/10.3102/00028312032003583

Simmons, R. G., \& Blyth, D. A. (1987). Moving into Adolescence: The Impact of Pubertal Change and School Context. Hawthorne, NJ: Aldine.

Singh, K., Granville, M. \& Dika, S. (2002). Mathematics and Science Achievement: Effects of Motivation, Interest, and Academic Engagement. The Journal of Educational Research, 95, 323-332.

Wang, C. (2004). Gendai chugoku no kyouiku [Current Education Situation in China]. Tokyo: Akashi Shoten.

Wentzel, K. R. (1998) Social Relationships and Motivation in Middle School. Journal of Educational Psychology, 90, 202-209. https://doi.org/10.1037/0022-0663.90.2.202

Wentzel, K. R., Weinberger, D. A., Ford, M. E., \& Feldman, S. S. (1990). Academic Achievement in Preadolescence: The Role of Motivational, Affective, and Self-Regulatory Processes. Journal of Applied Developmental Psychology, 11, 179-193.

https://doi.org/10.1016/0193-3973(90)90004-4 